\title{
PENGETAHUAN IBU YANG MEMILIKI BAYI DAN BALITA TENTANG KAPSUL VITAMIN A DI BPM DYAH WIDYA KISMOYOSO NGEMPLAK BOYOLALI TAHUN 2018
}

\author{
KNOWLEDGE OF INFANT AND TODDLER MOTHERS \\ ABOUT VITAMIN A CAPSULES IN BPM DYAH WIDYA \\ KISMOYOSO NGEMPLAK BOYOLALI YEAR 2018
}

\author{
Catur Setyorini \\ STIKES Mamba'ul 'Ulum Surakarta \\ (catur.ririn@yahoo.co.id)
}

\begin{abstract}
ABSTRAK
Latar Belakang Masalah: Vitamin A adalah zat gizi yang paling esensial, hal itu dikarenakan konsumsi makanan kita belum mencukupi dan masih rendah sehingga harus dipenuhi dari luar. Kekurangan Vitamin A (KVA) dapat menurunkan sistem kekebalan tubuh balita serta meningkatkan risiko kesakitan dan kematian. Kekurangan Vitamin A juga merupakan penyebab utama kebutaan pada anak yang dapat dicegah. Tujuan penelitian ini adalah mengetahui pengetahuan ibu yang memiliki bayi balita tentang kapsul vitamin A di BPM Dyah Widya Kismoyoso Ngemplak Boyolali Tahun 2018 dengan karakteristik usia dan paritas.

Desain penelitian: Penelitian ini merupakan penelitian deskriptif dengan pendekatan cross sectional. sampel dalam penelitian ini adalah ibu yang memiliki bayi dan balita yang dijumpai saat dilakukan penelitian pada bulan Maret $2018 \mathrm{di}$ BPM Dyah Widya Kismoyoso Ngemplak Boyolali sejumlah 30 orang. Alat pengumpulan data menggunakan kuesioner. Analisis data dengan analisis Univariate menggunakan rumus distribusi frekuensi.

Hasil penelitian: Karakteristik responden mayoritas berusia 26-35 tahun sejumlah 18 responden (60\%), mayoritas multipara sejumlah 25 responden $(83,3 \%)$ dan tingkat pengetahuan responden berpengetahuan baik sejumlah 16 responden $(53,3 \%)$ dan pengetahun cukup sejumlah 14 responden $(46,7 \%)$.

Simpulan: Dalam penelitian ini mayoritas pengetahuan ibu yang memiliki bayi balita tentang kapsul vitamin A di BPM Dyah Widya Kismoyoso Ngemplak Boyolali tahun 2018 dalam kategori baik.
\end{abstract}

Kata Kunci: Pengetahuan, Kapsul Vitamin A

\section{ABSTRACT}

Background: Vitamin $A$ is the most essential nutrient, it is because our food consumption is not sufficient and still low so it must be met from outside. Vitamin $A$ deficiency (KVA) can lower the immune system of children under five and increase the risk of illness and death. Vitamin A deficiency is also a major cause of preventable childhood blindness. The purpose of this study is to know the knowledge of mothers who have babies about vitamin A capsules in BPM Dyah Widya Kismoyoso Ngemplak Boyolali Year 2018 with the characteristics of age and parity. 
Method: The research design is descriptive research with cross sectional approach. the sample in this study were mothers who had infants and toddlers who were encountered during the research in March 2018 at BPM Dyah Widya Kismoyoso Ngemplak Boyolali a number of 30 people. The data collection tool uses questionnaires. Data analysis with Univariate analysis using frequency distribution formula.

Result: The result of research is characteristic of majority respondent aged 2635 years old number 18 respondent (60\%), multiparity majority 25 respondents $(83,3 \%)$ and knowledge level of respondent good knowledge 16 respondents $(53,3 \%)$ and enough knowledge 14 respondents (46.7\%).

Conclusion: Conclusions in this study the majority of knowledge of mothers who have babies about vitamin A capsule in BPM Dyah Widya Kismoyoso Ngemplak Boyolali in 2018 in good category.

Keywords: Knowledge, Vitamin A Capsule

\section{PENDAHULUAN}

Vitamin A adalah vitamin larut lemak yang pertama ditemukan. Vitamin A esensial untuk pemeliharaan kesehatan dan kelangsungan hidup. Di seluruh dunia (WHO, 1991), diantara anak-anak prasekolah diperkirakan terdapat sebanyak 6-7 juta kasus baru xeropthalmia tiap tahun, kurang lebih 10\% diantaranya menderita kerusakan kornea. Diantara yang menderita kerusakan kornea ini $60 \%$ meninggal dalam waktu satu tahun, sedangkan diantara yang hidup 25\% menjadi buta dan 50-60\% setengah buta. Diperkirakan pada satu waktu sebanyak 3 juta anak-anak buta karena kekurangan vitamin A, dan sebanyak 20- 40 juta menderita kekurangan vitamin A pada tingkat lebih ringan. Perbedaan angka kematian antara anak yang kekurangan dan tidak kekurangan vitamin A kurang lebih sebesar 30\%. Di samping itu kekurangan vitamin A meningkatkan risiko anak terhadap penyakit infeksi seperti penyakit saluran pernafasan dan diare, meningkatkan angka kematian karena campak, serta menyebabkan keterlambatan pertumbuhan. Penelitian-penelitian selama dua puluh tahun terakhir memberikan bukti-bukti lebih nyata bahawa kekurangan vitamin A tidak menyebabkan kebutaan saja, tetapi berdampak buruk terhadap kesehatan anak dan kelangsungan hidup anak secara keseluruhan (Almatsier, 2000).

Kekurangan (defisiensi) vitamin A terutama terdapat pada anak-anak balita. Tanda-tanda kekurangan terlihat bila simpanan tubuh habis terpakai. Kekurangan vitamin A dapat merupakan kekurangan primer akibat kurang konsumsi, atau kekurangan sekunder karena gangguan penyerapan dan penggunaan dalam tubuh, kebutuhan yang meningkat ataupun karena gangguan pada koversi karoten menjadi vitamin A. Kekurangan vitamin A sekunder dapat terjadi pada penderita Kurang Energi Protein (KEP), penyakit hati, alfa, betalipoproteinemia atau gangguan absorpsi karena kekurangan asam empedu. Kekurangan vitamin A banyak terdapat di Negara-negara berkembang termasuk di Indonesia karena makanan kaya vitamin A pada 
umumnya mahal harganya. Tanda pertama kekurangan vitamin A adalah rabun senja. Suplementasi vitamin A dapat memperbaiki penglihatan yang kurang bila itu disebabkan oleh kekurangan vitamin A (Almatsier, 2000).

Program penanggulangan kurang vitamin A (KVA) telah dilaksanakan sejak tahun 1970-an dan sampai saat ini masih merupakan salah satu masalah gizi utama di Indonesia. Strategi penanggulangan kurang vitamin A masih beretumpu pada pemberian kapsul vitamin A dosisi tinggi yang diberikan pada bayi (6-11 bulan), balita (1-5tahun) dan ibu nifas berdasarkan laporan tahun 1998/1999, cakupan pemberian kapsul vitamin A pada balita masih dibawah $70 \%$ dan ibu nifas sekitar 40\%, sedangkan pemberian kapsul vitamin A pada bayi (6-11 bulan) baru dimulai sejak dicanangkan oleh Menteri Kesehatan RI pada bulan Februari 1999 (DepKes RI. 2000)

Berdasarkan Profil Kesehatan Indonesia Tahun 2016 menunjukkan persentase balita 6-59 bulan di Indonesia yang mendapatkan vitamin A sebesar 90,1\% lebih tinggi dari target nasional sebesar 82\%. Cakupan pemberian Vitamin A pada balita 6-59 bulan tertinggi yaitu Provinsi Gorontalo sebesar 95,0\% dan terendah di Papua sebesar 75,3\%. Persentase balita 6-11 bulan mendapat kapsul vitamin A sebesar 69,1\% sedangkan pada balita 12-59 bulan sebesar 93,2\%. Berdasarkan data yang diperoleh dari Profil Kesehatan Kabupaten/ Kota di Jawa Tengah tahun 2016 menunjukkan cakupan pemberian suplementasi kapsul vitamin A dosis tinggi pada balita 92,9\%.

Ketidaktahuan ibu tentang vitamin A pada balita merupakan salah satu faktor balita tidak mendapatkan vitamin A sehingga mereka rentan terhadap infeksi. Kurangnya penyuluhan yang dilakukan oleh para kader kepada masyarakat, ketidaktahuan ibu tempat dimana ibu dapat memperoleh vitamin A serta kurangnya kesadaran masyarakat terhadap pentingnya mengikuti posyandu juga merupakan faktor- faktor yang menyebabkan balita kekurangan vitamin A (Mursudarinah, dkk)

Hasil wawancara saat studi pendahuluan di BPM Dyah Widya Posyandu pada 4 ibu yang memiliki balita didapatkan tingkat pengetahuan ibu tentang manfaat vitamin A dalam kategori cukup. Berdasarkan uraian di atas, maka peneliti tertarik untuk mengetahui "Pengetahuan Ibu yang memiliki bayi dan balita tentang kapsul vitamin A di BPM Dyah Widya Kismoyoso Ngemplak Boyolali Tahun 2018.

\section{METODE PENELITIAN}

Penelitian ini merupakan penelitian deskriptif dengan pendekatan cross sectional. Populasi penelitian ini adalah seluruh ibu yang memiliki bayi dan balita di BPM Dyah Widya Kismoyoso Ngemplak Boyolali. Teknik pengambilan sampel dengan Accidental Sampling, sehingga sampel dalam penelitian ini adalah ibu yang memiliki bayi dan balita yang dijumpai saat dilakukan penelitian pada bulan Maret 2018 di BPM Dyah Widya Kismoyoso Ngemplak Boyolali sejumlah 30 orang. 
Pada penelitian ini menggunakan alat pengumpul data berupa kuesioner, jenis kuesioner dalam penelitian ini adalah kuesioner tertutup dengan skala Guttman pada pernyataan positif jawaban benar: 1 dan jawaban salah: 0, dan pernyataan negatif jawaban benar: 0 dan jawaban salah: 1 . Berdasarkan hasil uji validitas dari 34 soal terdapat 3 butir soal yang tidak valid dan selanjutnya soal yang tidak valid dihilangkan atau tidak dipakai dalam penelitian. Hasil perhitungan realibilitas sangat tinggi menunjukan bahwa kuesioner pengetahuan memiliki koefisien reliabilitas sebesar 0,914.

Metode pengumpulan data yang digunakan adalah pengumpulan data primer dan sekunder. Dalam penelitian ini pengumpulan data primer dilakukan dengan membagikan kuesioner secara langsung kepada ibu yang memiliki bayi dan balita, sedangkan pengumpulan data sekunder dilakukan dengan cara melihat dokumen-dokumen atau catatan-catatan yang mendukung data penelitian, seperti buku kunjungan pasien. Dalam penelitian ini menggunakan analisis univariate.

\section{HASIL DAN PEMBAHASAN}

Penelitian mengenai gambaran pengetahuan ibu yang memiliki bayi dan balita tentang kapsul vitamin A di BPM Dyah Widya Kismoyoso Ngemplak Boyolali Tahun 2018 dengan hasil sebagai berikut :

Tabel 1 Distribusi Frekwensi Karakteristik Responden Berdasarkan Umur, dan Paritas

\begin{tabular}{lcc}
\hline \multicolumn{1}{c}{ Karakteristik } & Frekwensi (f) & $\begin{array}{c}\text { Prosentase } \\
(\%)\end{array}$ \\
\hline Umur & 6 & 20,0 \\
$16-25$ tahun & 18 & 60,0 \\
$26-35$ tahun & 6 & 20,0 \\
$36-45$ tahun & & 100 \\
\hline Total & 30 & \\
\hline Paritas & & 16,7 \\
Primipara & 5 & 83,3 \\
Multipara & 25 & 0 \\
Grandemultipara & 0 & 100 \\
\hline Total & & \\
\hline
\end{tabular}

Berdasarkan Tabel 1 dapat dilihat bahwa menurut karakteristik umur responden mayoritas adalah umur 26 - 35 tahun yaitu 18 orang (60\%), dan menurut karakteristik paritas mayoritas adalah multipara yaitu ada 25 orang $(83,3 \%)$ 
Tabel 2 Distribusi Frekuensi Variabel Pengetahuan Ibu yang Memiliki Bayi dan Balita tentang kapsul Vitamin A di BPM Dyah Widya Kismoyoso Ngemplak Boyolali Tahun 2018

\begin{tabular}{ccc}
\hline Pengetahuan & Frekuensi (f) & Prosentase (\%) \\
\hline Baik & 16 & 53,3 \\
Cukup & 14 & 46,7 \\
Kurang & 0 & 0 \\
Total (n) & 30 & 100 \\
\hline
\end{tabular}

Berdasarkan hasil penelitian pada tabel 2 dapat dilihat bahwa pengetahuan ibu yang memiliki bayi dan balita tentang vitamin A dengan kategori pengetahuan baik sebanyak 16 responden $(53,33 \%)$, kategori pengetahuan cukup sebanyak 14 responden (46,7\%) dan tidak ada responden dengan pengetahuan kurang.

Vitamin A adalah salah satu zat gizi penting yang larut dalam lemak, disimpan dalam hati, dan tidak dapat diproduksi oleh tubuh sehingga harus dipenuhi dari luar tubuh. Kekurangan Vitamin A (KVA) dapat menurunkan sistem kekebalan tubuh balita serta meningkatkan risiko kesakitan dan kematian. Kekurangan Vitamin A juga merupakan penyebab utama kebutaan pada anak yang dapat dicegah.

Dalam lampiran Peraturan Menteri Kesehatan Nomor 21 Tahun 2015, dinyatakan bahwa untuk mengurangi risiko kesakitan dan kematian pada balita dengan kekurangan Vitamin A, pemerintah menyelenggarakan kegiatan pemberian Vitamin A dalam bentuk kapsul vitamin A biru 100.000 IU bagi bayi usia enam sampai dengan sebelas bulan, kapsul vitamin A merah 200.000 IU untuk anak balita usia dua belas sampai dengan lima puluh sembilan bulan, dan ibu nifas.

Menurut Panduan Manajemen Suplementasi Vitamin A, pemberian suplementasi Vitamin A diberikan kepada seluruh balita umur 6 -59 bulan secara serentak melalui posyandu yaitu; bulan Februari atau Agustus pada bayi umur 6-11 bulan serta bulan Februari dan Agustus pada anak balita 1259 bulan. (Profil Kesehatan Indonesia, 2016)

Pengetahuan merupakan hasil tahu dan hal ini terjadi setelah orang melakukan penginderaan terhadap sesuatu objek tertentu. Penginderaan terjadi melalui panca indra manusia yaitu indra penglihatan, pendengaran, penciuman, peraba, dan perasa. Sebagian besar pengetahuan diperoleh melalui mata, telinga, pengetahuan atau kognitif merupakan domain yang sangat penting untuk terbentuknya tindakan seseorang (overt behavior). Pengetahuan dipengaruhi oleh faktor internal dan faktor eksternal. Faktor internal meliputi pendidikan, pekerjaan, dan umur. Faktor eksternal yang mempengaruhi pengetahuan meliputi lingkungan dan sosial budaya. (Wawan, 2011)

Selain dipengaruhi oleh faktor internal dan eksternal sebagaimana dijelaskan diatas, pengetahuan dalam domain kognitif juga memiliki tingkatan 
ataupun tahapan yang meliputi tahap: Tahu (know); Memahami (comprehension); Aplikasi (aplication); Analisa (analysis); Sintesis (syntesis); dan Evaluasi (evaluation) (Fitriani, 2011).

Hasil penelitian didapatkan mayoritas responden berpengetahuan baik sejumlah 16 responden (53,3\%). Responden dengan pengetahuan baik berarti ibu sudah memahami tentang vitamin A meliputi pengertian, manfaat, kebutuhan, jadwal pemberian, diagnosis kekurangan vitamin $\mathrm{A}$, penyebab kekurangan vitamin $A$, tanda dan gejala kekurangan vitamin $A$, pencegahan dan pengobatan vitamin $A$. Responden dengan pengetahuan baik mayoritas berumur 26-35 tahun sebanyak 9 responden dan dengan paritas multipara sebanyak 13 responden.

Dalam penelitian ini faktor yang mempengaruhi pengetahuan adalah usia. Usia adalah umur individu yang terhitung mulai saat dilahirkan sampai berulang tahun. Semakin cukup umur, tingkat kematangan dan kekuatan seseorang akan lebih matang dalam berfikir dan bekerja sehingga pengetahuan yang diperolehnya semakin membaik. Dari segi kepercayaan masyarakat, seseorang yang lebih dewasa dipercaya dari orang yang belum tinggi kedewasaannya (Wawan, 2011). Berdasarkan hasil penelitian diketahui sebagian besar responden berumur 26 - 35 tahun yaitu sebanyak 18 responden (60\%). Dimana diharapkan pada usia tersebut sudah terbentuk usia dewasa, apabila usia bertambah maka akan lebih banyak informasi dan pengalaman yang didapat, namun masih ada 9 responden dengan usia 26-35 tahun dengan pengetahuan cukup hal itu disebabkan karena tidak diimbangi dengan media informasi yang didapat. Paparan media masa baik cetak maupun elektronik menyebabkan berbagai informasi dapat diterima dengan mudah oleh masyarakat, sehingga seseorang yang lebih sering terpapar media massa (televisi, radio, majalah, pamflet, dan lain-lain) akan memperoleh informasi lebih banyak jika dibandingkan dengan orang yang tidak pernah terpapar informasi media (Wawan, 2011).

Di usia 16-25 tahun sebanyak 4 responden juga berpengetahuan baik, Usia 16-25 tahun merupakan masa-masa usia aktif dan produktif, sehingga seseorang cenderung aktif dalam mencari berbagai informasi yang ditunjang dengan adanya rasa keingintahuan yang besar serta dukungan akses informasi melalui media sosial yang hampir semua orang dalam kategori usia tersebut aktif mengakses dan memanfaatkan media sosial sebagai sarana informasi. Dari 16 responden yang memiliki pengetahuan baik tersebut jika dilihat dari paritasnya yaitu 3 responden primipara dan 13 responden multipara. Paritas merupakan jumlah anak yang dilahirkan oleh ibu baik dalam keadaan hidup maupun mati. Paritas disini berhubungan dengan pengalaman ibu, semua pengalaman pribadi merupakan sumber pengetahuan untuk menarik kesimpulan dan pengalaman. (Notoadmojo, 2010)

Responden dengan pengetahuan dalam kategori cukup ada 14 responden (46,7\%), mayoritas berada dalam kategori umur 26-35 tahun sebanyak 9 responden dan paritas multipara sebanyak 12 responden. Pada umur madya (40-60 tahun), individu akan lebih berperan aktif dalam 
masyarakat dan kehidupan sosial serta lebih banyak melakukan persiapan demi suksesnya upaya menyesuaikan diri menuju usia tua. Selain itu, orang umur madya juga akan lebih banyak menggunakan banyak waktunya untuk membaca, dan dari kemampuan intelektual, pemecahan masalah, maupun kemampuan verbal dilaporkan hampir tidak ada penurunan pada kategori umur ini (Wawan, 2011).

Hasil Penelitian ini memiliki kesesuaian dengan penelitian dari Mursudarinah tahun 2014 mengenai "Gambaran Tingkat Pengetahuan Ibu tentang Vitamin A pada Balita di Posyandu Nusa Indah XVIII Cemani Kabupaten Sukoharjo" dengan hasil Pengetahuan ibu tentang vitamin A pada balita di posyandu Nusa Indah XVIII Cemani dalam kategori cukup yaitu 59 responden $(60,82 \%)$ dan sejalan dengan penelitian yang telah dilakukan oleh Frida Cahyaningrum tahun 2017 mengenai "Hubungan Tingkat Pengetahuan Ibu tentang Vitamin A dengan Kepatuhan Ibu Memberikan Kapsul Vitamin A pada Balita Uisa 12-59 bulan di Wilayah Kerja Puskesmas Rowosari Kota Semarang", dimana hasil penelitiannya menunjukkan bahwa sebagian besar responden dengan tingkat pengetahuan cukup dan baik sebanyak 24 responden $(68,6 \%)$

\section{SIMPULAN DAN SARAN}

\section{Simpulan}

Pengetahuan ibu yang memiliki bayi dan balita tentang vitamin A di BPM Dyah Widya Kismoyoso Ngemplak Boyolali Tahun 2018 mayoritas dalam kategori baik sebanyak 16 responden (53,3\%). Karakteristik yang memiliki bayi dan balita tentang vitamin A di BPM Dyah Widya Kismoyoso Ngemplak Boyolali Tahun 2018 menunjukkan sebagian besar berumur 26 - 35 tahun sebanyak 18 responden (60\%) dan multipara sebanyak 25 responden $(83,3 \%)$

\section{Saran}

Bagi Bidan hendaknya terus-menerus berupaya untuk memberi informasi melalui kegiatan penyuluhan kepada ibu bayi balita tentang pentingnya pemberian vitamin A pada bayi dan balita. Bagi Ibu hendaknya lebih meningkatkan pengetahuan dan kesadaran tentang pentingnya pemberian vitamin A yang sangat bermanfaat bagi bayi dan balita.

\section{DAFTAR PUSTAKA}

Almatsier. 2009. Prinsip Dasar Ilmu Gizi. Jakarta: PT Gramedia Pustaka Utama DepKes RI. 2000. Pedoman Akselerasi Cakupan Kapsul Vitamin A. Jakarta: DepKes RI

Fitriani, Sinta. 2011. Promosi Kesehatan. Yogyakarta: Graha Ilmu

Frida Cahyaningrum, dkk. 2017. Hubungan Tingkat Pengetahuan Ibu tentang Vitamin A dengan Kepatuhan Ibu Memberikan Kapsul Vitamin A pada Balita Uisa 12-59 bulan di Wilayah Kerja Puskesmas Rowosari Kota 
Semarang. Jurnal Maternal Vol II No 1. Diakses dari

http://ejurnal.stikesmhk.ac.id

Mursudarinah, dkk. 2014. Gambaran Tingkat Pengetahuan Ibu tentang

Vitamin A pada Balita di Posyandu Nusa Indah XVIII Cemani Kabupaten

Sukoharjo. Diakses dari

http://ejurnal.akbidcm.ac.id/index.php/maternity/article/view/17

Notoatmodjo, S. 2010. Metode Penelitian Kesehatan. Jakarta: Rineke cipta

Profil Kesehatan Indonesia Tahun 2016. Diakses dari

http://www.depkes.go.id/resources/download/pusdatin/profil-

kesehatan-indonesia/Profil-Kesehatan-Indonesia-2016.pdf

Wawan, A \& Dewi, M. 2011. Pengetahuan Sikap dan Perilaku. Yogyakarta:

Nuha Medika 